\section{Regards sur l'économie allemande}

Bulletin économique du CIRAC

65 | 2004

Varia

\title{
Fiscalité des entreprises
}

PRANGENBERG Arno, Grundzüge der Unternehmensbesteuerung. Betriebswirtschaftliche Handlungshilfen

\section{(2) OpenEdition}

\section{Journals}

Édition électronique

URL : http://journals.openedition.org/rea/3960

DOI : $10.4000 /$ rea.3960

ISBN : 978-2-8218-0826-3

ISSN : 1965-0787

Éditeur

CIRAC

Édition imprimée

Date de publication : 1 mars 2004

ISSN : 1156-8992

Référence électronique

"Fiscalité des entreprises », Regards sur l'économie allemande [En ligne], 65 | mars 2004, mis en ligne le 29 octobre 2009, consulté le 22 septembre 2020. URL : http://journals.openedition.org/rea/3960 ; DOI : https://doi.org/10.4000/rea.3960

Ce document a été généré automatiquement le 22 septembre 2020

(C) CIRAC 


\section{Fiscalité des entreprises}

PRANGENBERG Arno, Grundzüge der Unternehmensbesteuerung. Betriebswirtschaftliche Handlungshilfen

\section{RÉFÉRENCE}

PRANGENBERG Arno, Grundzüge der Unternehmensbesteuerung.

Betriebswirtschaftliche Handlungshilfen, Edition der Hans Böckler Stiftung,

Düsseldorf, 2003, 76 p.

1 Les salariés allemands co-décidant de la marche des affaires dans l'entreprise, ils doivent connaître les contraintes qui pèsent sur le management pour mieux l'accompagner dans ses décisions. Voici donc une initiation à la fiscalité des entreprises réalisée par la Fondation Böckler du DGB. (IB) 